\title{
A Study to Determine the Impact of Transformational Leadership on the Growth of Profits in Start-Up Companies in Bangalore City
}

\author{
Mr. Prasad L $\mathbf{L}^{1}$ \& Dr. Noor Firdoos Jahan ${ }^{2}$ \\ ${ }^{1}$ Research Scholar and Associate Professor, Ramaiah Institute of Management Studies, No. \\ 23, M S Ramaiah Road, Gokula, Bangalore, India \\ ${ }^{2}$ Professor, R. V. Institute of Management, CA 17, 26 $6^{\text {th }}$ Main, $36^{\text {th }}$ Cross, $4^{\text {th }}$ T Block, \\ Jayanagar, Bangalore, India.
}

DOI - http://doi.org/10.37502/IJSMR.2021.4806

\begin{abstract}
Entrepreneurship, over the ages has seen tremendous transformation in terms of the objectives of entrepreneurship to the way entrepreneurs are finding new ways to fund their ventures and rake in profits. Not to forget the innovation quotient associated with entrepreneurship. Innovation has reached new heights, thanks mainly to emerging technologies such as Analytics, Design Thinking, Artificial Intelligence, Machine Learning, Robotics, etc.

The profile of the $21^{\text {st }}$ century entrepreneur has changed quite significantly with respect to age, educational qualifications, and prior experience. The new age entrepreneur is young, ambitious, innovative fearless, well-educated and has just about sufficient work experience to immerse himself into the exciting journey of new venture creation. From a socio-cultural perspective too there has been a significant shift in the way the India society looks at entrepreneurs. No longer are entrepreneurs looked down upon in society for their failures, especially keeping in mind that the failure rate of start-ups is more than $90 \%$ currently. Society has begun to accept the ups and downs of entrepreneurship in a positive way. The Central and State Governments too have recognised that start-ups are the need of the day to generate employment on a large scale and have come up with policies to encourage, fund and nurture start-ups.

This research paper tries to examine the connection between the leadership style of the founders with specific reference to Transformational Leadership style and the growth of profits of the start-ups. A survey was conducted in Bangalore City wherein a questionnaire covering demographic data and the Multifactor Leadership Questionnaire (a standard tool used by researchers worldwide to measure Transformational, Transactional and Passive-Avoidant leadership styles) was sent to 476 founders of start-ups. The responses were analysed using statistical tools such as Regression Analysis and Anova to determine whether Transformational Leadership style has an impact on the growth of profits of start-ups or not. The hypothesis was tested using the independent $\mathrm{t}$-test.
\end{abstract}

The analysis of data did not point towards a strong connection between Transformational Leadership and growth in profits of the start-ups.

Keywords: Entrepreneurship, Start-ups, Leadership, Transformational Leadership, Profits 


\section{Introduction}

The Start-up India Action Plan, notified on the $17^{\text {th }}$ of February, 2016 in the Gazette of India is an initiative of the Government of India to build a strong ecosystem in the country for nurturing innovation and start-ups. Also, the Plan aims to drive sustainable economic growth and generate large scale employment. The Plan envisages to provide funding support to entrepreneurs through a massive fund of funds totalling to a corpus of Rs.10, 000 crores. The action plan is to oversee the process through collaboration with more than a 100 incubators and 20 industry associations.

Not to be left behind, Karnataka State announced its Karnataka Start-up Policy 2015-20 in April 2016 with a vision of giving wings to start-ups in the state through strategic investment and policy interventions by leveraging the robust investment climate in Bangalore.

Bangalore plays a key role in the state's start-up policy and not without a reason. According to the Global Start-up Ecosystem report 2020 released by Startup Genome and Global Entrepreneurship Network, Bangalore is ranked $26^{\text {th }}$ in the world and is the only Indian City to rank amongst the top 30 start-up ecosystems in the world. The City was ranked \#15 in 2015 and as is evident, the City has dropped down considerably in its ranking over the 5 year period. One of the possible reasons for this is the Covid 19 pandemic that engulfed the entire world in 2020 severely affecting the business climate cutting across countries. But, due credit will have to be given to the resilience of the start-up community in Bangalore which saw opportunities in the downturn created by the Covid 19 pandemic and was quickly able to respond with innovative solutions in the areas of Healthtech, Edutech, Fintech, Foodtech, and e-Commerce. The result - these sectors actually benefited from the Covid 19 induced lockdowns where mobility of people was restricted and people got an opportunity to get uninterrupted services delivered to their homes in a safe and secure manner. However, there was collateral damage to the industry as a whole in Bangalore City due to the Covid 19 pandemic and scores of business establishments and start-ups had to close down. In this context, this research paper tries to examine the impact of Transformational Leadership in not just sustaining the profits of the companies but also ensuring growth in profits.

\section{Review of Literature}

(Northouse, 2012) says that Transformational Leadership is all about the leader influencing the follower to achieve more than what is expected from them by making use of charismatic and visionary leadership. Transformational Leadership is different from Transactional Leadership. Transactional Leadership focuses on the exchange that happens between leaders and followers, whereas Transformational Leadership is all about the leader engaging with a follower and influencing him to achieve more than what he is capable of.

Manfred F. R. Kets de Vries (1985), in an article "The dark side of entrepreneurship" defines entrepreneurs as being achievement oriented, willing to take responsibility for decisions and not having a liking for repetitive, routine work. He also says that entrepreneurs high levels of 
energy, great degree of perseverance and imagination, and are willing to take moderate and calculated risks. Entrepreneurs have the ability to instil enthusiasm in their teams which are contagious and they convey a sense of purpose. They are action oriented and do not like taking direction from others. They have a high need for control, have a sense of distrust, and always desire applause

Stephanie J. Arthur and Robert D. Hisrich (2011) in "Entrepreneurship through the ages: lessons learned" say that there are no formula or prescribed path for success of entrepreneurial ventures. They list down some of the common attributes of entrepreneurial leaders as: being a visionary, being passionate about the idea, risk taking ability, being perseverant, ability to build a team, being able to recognise opportunities and needs, solving problems faced by customers, and giving back to society

Yunxia Zhu and M. Zhang Alee (2008), in the Academy of Management Perspectives talk about the word "New Technology Ventures" being associated with survival, risk, success, and failure. They elucidate that new technology ventures have a limited survival rate, with only $36 \%$ of them surviving four years, and even lesser proportions found to be operating after five years. They quote a detailed meta-analysis of the data from 31 empirical studies which point towards marketing, opportunity, the entrepreneurial team, and resources being major factors that influence the success or failure of new technology ventures. They state that the market scope had a direct relationship with the success of start-ups

Dean Elmuti et al (2012), in a research article "Does entrepreneurship education have a role in developing entrepreneurial skills and venture's effectiveness?" discuss the impact that entrepreneurial education and training has in developing and enhancing the much needed entrepreneurial skills required to improve the effectiveness of a venture. Based on a study of 170 entrepreneurs, they conclude that entrepreneurial education (managerial skills), social competence (inter-personal skills), and training on basic entrepreneurial skills have an impact on the effectiveness of the venture

In an article titled "How do entrepreneur's Emotional Intelligence and Transformational Leadership orientation impact new venture growth", Romit Yitshaki (2012) says it is not Intelligence Quotient but it is the Emotional Intelligence and social capabilities of the leader which determines the leader's performance.

Peter Bregman (2013), in his article "The most overlooked leadership skill”, says that it is the ability of the leader to receive messages that distinguishes the best of the leaders from the rest, more than the ability of the leader to convey messages clearly and powerfully. He says that a great leader can become a great receiver by being courageous, not judging and by being open.

\section{Objectives of the Study}

- To get an understanding of start-ups and their position in Bangalore City

- To explore Transformational Leadership 
- To determine the impact of Transformational Leadership on the growth of profits in start-up companies in Bangalore City.

\section{Research Methodology}

The research methodology chosen for the study is descriptive and exploratory in nature. A survey covering 476 founders of start-up companies in Bangalore City was done. A questionnaire comprising demographic data and questions pertaining to the leadership style of the founders was circulated to collect the primary data for the research and the responses were analysed using statistical tools such as Regression Analysis and Anova. The Multifactor Leadership Questionnaire was used to determine the leadership styles of the founders. The hypothesis was tested using the independent t-test. The sampling method chosen for the data collection was Probability Sampling and the sampling technique chosen was Simple Random Sampling. Secondary data was collected from research articles published in journals, other published sources, and the Internet. The hypothesis used for the study was "Transformational Leadership no impact on the growth of profits in start-up ventures in Bangalore City".

\section{Findings}

Of the 476 respondents, 393 were male and 83 were female. On being asked whether the profits of their companies had increased compared to the previous year, $47 \%$ of the respondents said yes and $53 \%$ of the respondents said no.

\subsection{Regression Analysis Using SPSS for Profits}

Regression Analysis was used to determine the impact of the independent variables (questions 16 to 60 pertaining to leadership) on the dependent variable (profits) and also to explore the relationship between the dependent and independent variables.

Table 5.0: Coefficients ${ }^{\mathrm{a}}$ 
73 | International Journal of Scientific and Management Research 4(8) 69-77

\begin{tabular}{|c|c|c|c|c|c|c|}
\hline \multirow{2}{*}{\multicolumn{2}{|c|}{ Model }} & \multicolumn{2}{|c|}{ Unstandardized Coefficients } & \multirow{2}{*}{$\begin{array}{c}\begin{array}{c}\text { Standardized } \\
\text { Coefficients }\end{array} \\
\text { Beta }\end{array}$} & \multirow[t]{2}{*}{$\mathrm{t}$} & \multirow[t]{2}{*}{ Sig. } \\
\hline & & B & Std. Error & & & \\
\hline \multirow{33}{*}{1} & (Constant) & 1.814 & .352 & & 5.161 & .000 \\
\hline & Q16 & -.033 & .059 & -.049 & -.554 & .580 \\
\hline & Q17 & -.062 & .061 & -.092 & -1.013 & .312 \\
\hline & Q18 & .054 & .051 & .097 & 1.056 & .291 \\
\hline & Q19 & .023 & .046 & .052 & .493 & .622 \\
\hline & Q20 & -.004 & .057 & -.006 & -.075 & .941 \\
\hline & Q21 & -.005 & .054 & -.010 & -.098 & .922 \\
\hline & Q22 & .040 & .095 & .038 & .420 & .675 \\
\hline & Q23 & .041 & .078 & .065 & .524 & .600 \\
\hline & Q24 & .001 & .073 & .001 & .009 & .993 \\
\hline & Q25 & .020 & .050 & .044 & .400 & .689 \\
\hline & Q26 & .023 & .050 & .042 & .462 & .644 \\
\hline & Q27 & -.014 & .064 & -.022 & -.219 & .827 \\
\hline & Q28 & .003 & .066 & .005 & .048 & .962 \\
\hline & Q29 & -.094 & .117 & -.147 & -.802 & .423 \\
\hline & Q30 & .022 & .050 & .043 & .440 & .660 \\
\hline & Q31 & .015 & .061 & .028 & .240 & .811 \\
\hline & Q32 & .048 & .042 & .107 & 1.144 & .253 \\
\hline & Q33 & -.008 & .057 & -.012 & -.144 & .886 \\
\hline & Q34 & .001 & .037 & .004 & .039 & .969 \\
\hline & Q35 & -.034 & .040 & -.078 & -.853 & .394 \\
\hline & Q36 & .001 & .046 & .002 & .023 & .982 \\
\hline & Q37 & .040 & .060 & .084 & .667 & .505 \\
\hline & Q38 & -.042 & .051 & -.071 & -.815 & .415 \\
\hline & Q39 & -.034 & .047 & -.080 & -.719 & .473 \\
\hline & Q40 & -.002 & .059 & -.005 & -.041 & .967 \\
\hline & Q41 & -.031 & .078 & -.054 & -.402 & .688 \\
\hline & Q42 & -.039 & .043 & -.084 & -.903 & .367 \\
\hline & Q43 & .026 & .048 & .039 & .541 & .589 \\
\hline & Q44 & -.055 & .083 & -.079 & -.655 & .513 \\
\hline & Q45 & -.006 & .095 & -.009 & -.060 & .952 \\
\hline & Q46 & -.026 & .089 & -.037 & -.297 & .767 \\
\hline & Q47 & -.028 & .086 & -.037 & -.325 & .745 \\
\hline
\end{tabular}




\begin{tabular}{|c|c|c|c|c|c|c|}
\hline \multirow{7}{*}{} & Q48 & -.016 & .052 & -.029 & -.300 & .764 \\
\cline { 2 - 7 } & Q49 & .081 & .077 & .125 & 1.059 & .290 \\
\cline { 2 - 7 } & Q50 & .006 & .089 & .008 & .070 & .945 \\
\hline & Q51 & .163 & .124 & .211 & 1.312 & .190 \\
\hline & Q52 & -.067 & .087 & -.094 & -.777 & .437 \\
\hline & Q53 & .026 & .065 & .041 & .394 & .694 \\
\hline & Q54 & .018 & .061 & .034 & .298 & .766 \\
\cline { 2 - 7 } & Q55 & .112 & .068 & .169 & 1.643 & .101 \\
\hline & Q56 & -.080 & .087 & -.103 & -.925 & .355 \\
\hline & Q57 & -.008 & .081 & -.010 & -.104 & .917 \\
\cline { 2 - 7 } & Q58 & -.084 & .083 & -.112 & -1.019 & .309 \\
\cline { 2 - 7 } & Q59 & -.008 & .086 & -.011 & -.094 & .925 \\
\hline
\end{tabular}

1. B Coefficients: The B Coefficients tell us how many units of profits increase for single unit increase in each predictor. Given only the scores on our predictors, we can predict the profits by computing in the formula:

Slope $(\mathrm{Y})=\mathrm{mx}+\mathrm{b}$; meaning $=\mathrm{Y}=1.814+(-0.033 \mathrm{X} \mathrm{Q} 16)+(-0.062 \mathrm{XQ} 17) \ldots . \&$ so on

2. The Column above mentioned as 'Sig' holds the $\mathrm{p}$-values for our predictors. As a rule in statistics, we always say that a B Coefficient is statistically significant if its p-value is smaller than 0.05. In the above table none of the Variables Coefficients are statistically significant

3. The beta Coefficients allow us to compare the relative strengths of our predictor.

4. The t-Statistic Column is used to check the null hypothesis Vs. alternate

\section{SPSS Regression Output - Model Summary Table}

Table 5.1: Model Summary

\begin{tabular}{|c|c|c|c|c|}
\hline Model & $\mathrm{R}$ & $\mathrm{R}$ Square & Adjusted R Square & Std. Error of the Estimate \\
\hline 1 & $.239^{\mathrm{a}}$ & .057 & -.042 & .510 \\
\hline
\end{tabular}

a. Predictors: (Constant), Q60, Q42, Q34, Q20, Q32, Q36, Q18, Q43, Q22, Q17, Q33, Q50, Q27, Q56, Q48, Q16, Q58, Q25, Q35, Q38, Q47, Q26, Q54, Q59, Q37, Q23, Q28, Q57, Q39, Q55, Q30, Q52, Q21, Q19, Q53, Q40, Q44, Q24, Q49, Q31, Q51, Q41, Q46, Q45, Q29

1. The model above predicts Profits. $\mathrm{R}$ denotes the Correlation between the predicted \& observed Profits.

2. R Square is simply the square of $\mathrm{R}$, this indicates the proportion of Variance in Profits that can be explained by all our predictors (Independent Variables). R Squared tells the researcher that how many points fall on the regression line. 
3. Since, Regression maximizes $\mathrm{R}$ Square, this will be somewhat lower for the entire population, a phenomenon known as shrinkage. The Adjusted R Square estimates the population R Square for our model above and thus ensures and gives a more realistic indication of its predictive power.

\subsection{Analysis of Variance (ANOVA)}

Anova gives an insight to the researcher about the total variation of the dependent variable (profit) to the explained and un-explained portions.

Table 5.2: ANOVA ${ }^{b}$

\begin{tabular}{|c|c|c|c|c|c|c|}
\hline \multicolumn{2}{|c|}{ Model } & Sum of Squares & Df & Mean Square & F & Sig. \\
\hline \multirow{3}{*}{1} & Regression & 6.768 & 45 & .150 & .578 & $.987^{\text {a }}$ \\
\cline { 2 - 7 } & Residual & 111.877 & 430 & .260 & & \\
\cline { 2 - 8 } & Total & 118.645 & 475 & & & \\
\hline
\end{tabular}

a. Predictors: (Constant), Q60, Q42, Q34, Q20, Q32, Q36, Q18, Q43, Q22, Q17, Q33, Q50, Q27, Q56, Q48, Q16, Q58, Q25, Q35, Q38, Q47, Q26, Q54, Q59, Q37, Q23, Q28, Q57, Q39, Q55, Q30, Q52, Q21, Q19, Q53, Q40, Q44, Q24, Q49, Q31, Q51, Q41, Q46, Q45, Q29

\section{b. Dependent Variable: Q12 (Profits)}

The above ANOVA table denotes that the regression model predicts the dependent variable significantly or not! It is observed from the "Regression" row and continue till the "Sig" column, this indicates the statistical significance of the regression model that was run above. Here $p$ value (.987) which is $>0.05$ and indicates that the overall regression model is not statistically significant and cannot predict the outcome variable which is Profit.

\subsection{Independent t-test to test the research hypotheses}

Null Hypothesis: Transformational Leadership has no impact on the growth of profits in start-up companies

Table 5.3: Group Statistics

\begin{tabular}{|c|c|c|c|c|c|}
\hline & Q12 (Profits) & $\mathrm{N}$ & Mean & Std. Deviation & Std. Error Mean \\
\hline \multirow{2}{*}{ Q60 } & Yes & 225 & 3.18 & .651 & .043 \\
\cline { 2 - 6 } & No & 251 & 3.14 & .691 & .044 \\
\hline
\end{tabular}


Table 5.4: Independent Samples Test

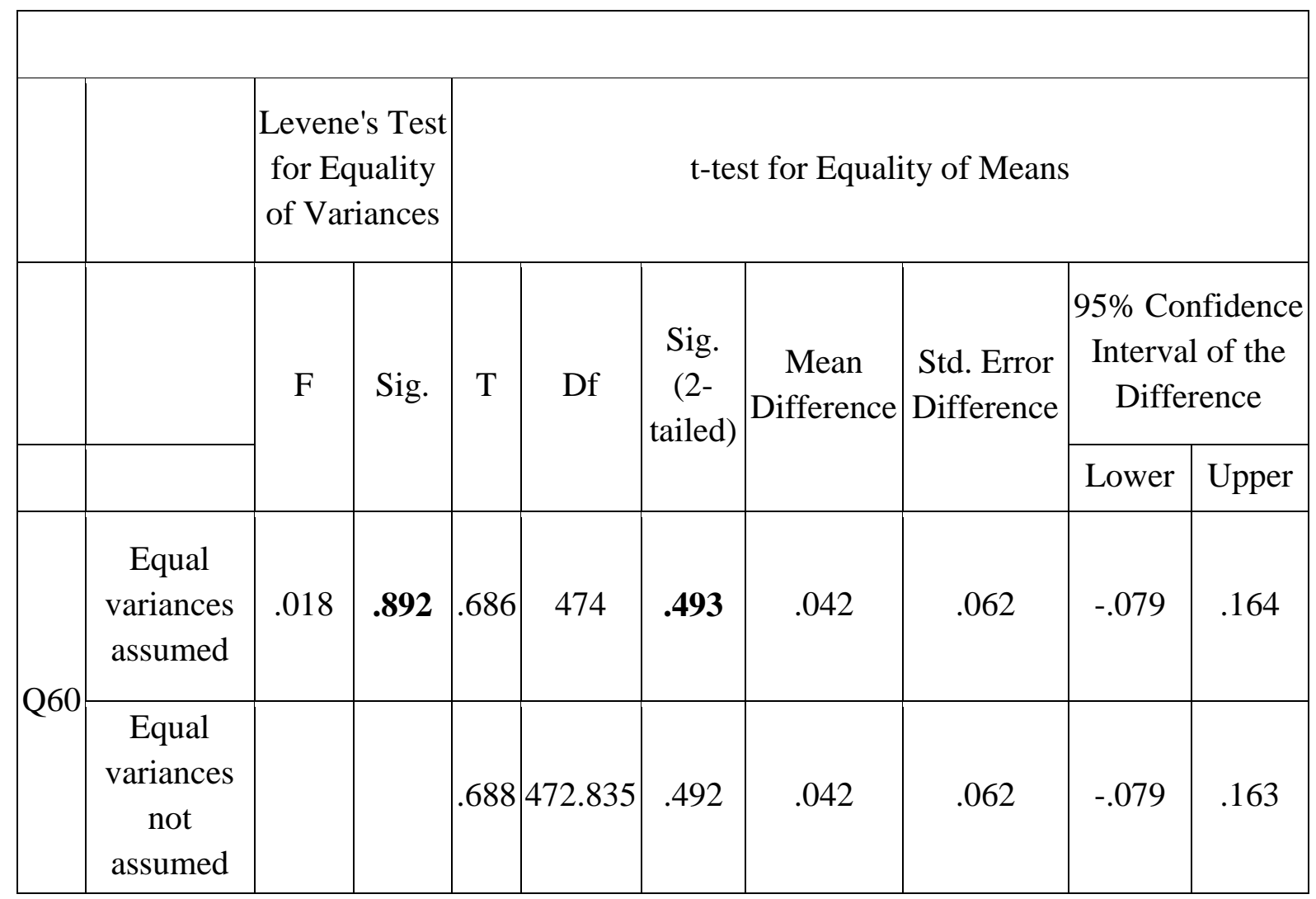

Conclusion: from the above Independent t-test, since $p>0.493$ ((2-tailed test)) is greater than our chosen significance level 0.05, the researcher does not reject the Null Hypothesis

\section{Suggestions and Conclusion}

The statistical analysis using Regression Analysis and Anova has shown that there is no significant impact of Transformational Leadership on the growth of profits in start-up companies and it is supported by the independent $\mathrm{t}$-test used to test the hypothesis. From this we can conclude that the null hypothesis cannot be rejected. Hence, Transformational Leadership has no impact on the growth of profits in start-up companies in Bangalore City.

Since the study was restricted to Bangalore City alone, it may not be a true representation of the relationship between Transformational Leadership and its impact on the growth of profits in start-ups. Moreover there could be other factors that influence profits in start-ups and these have not been considered in the study. Hence there could be a research gap, paving the way for further research on this topic.

\section{References}

1) "Start-up India Action Plan", Gazette of India, 2016 
2) “Karnataka Start-up Policy 2015-2020", 2016

3) "Global Start-up Ecosystem report 2020", Startup Genome and Global Entrepreneurship Network

4) Peter G. Northouse, "Leadership: Theory and Practice", Sage Publications, 2012

5) Manfred F. R. Kets de Vries, "The dark side of entrepreneurship", Harvard Business Review, November 1985

6) Stephanie J. Arthur and Robert D. Hisrich, "Entrepreneurship through the ages: lessons learned", Journal of Enterprising Culture, Vol.19, No.1, March 2011

7) Yunxia Zhu and M. Zhang Alee, "New technology ventures: What factors lead to success?", Academy of Management Perspectives, May 2008

8) Dean Elmuti et al, "Does entrepreneurship education have a role in developing entrepreneurial skills and venture's effectiveness?", Journal of Entrepreneurship Education, Vol 15, 2012

9) Romit Yitshaki, "Journal of Small Business Entrepreneurship", 2012

10) Peter Bregman, "The most overlooked leadership skill”, Harvard Business Review, May 2013 